\title{
The Effectiveness of Online Learning in Learning Chinese Language
}

\author{
Ivana
}

Universitas Prima Indonesia, Indonesia

\begin{abstract}
Mid-March 2020, Indonesia began to be hit by the COVID-19 pandemic, which forced the government to set up online learning. The purpose of this study was to find out how effectiveness online learning was applied by Mandarin language educators at the junior high school level at Methodist Charles Wesley. Analysis of the data used is data analysis Miles and Huberman. The results of this study are: (1) Educators and students have adequate facilities in online learning. (2) Online learning has flexibility in its implementation. However, online learning has its own challenges, namely: weak internet signal, high internet costs and lack of teacher supervision of students.
\end{abstract}

Keywords: Online Learning, Effectiveness, COVID-19

\section{INTRODUCTION}

The year 2020-2021 is a year that forces almost all people in Indonesia to use information and communication technology in everyday life, especially in the field of education. This is due to the COVID-19 pandemic and to suppress the spread of this virus, the government prohibits crowds and maintains physical distance, and stipulates that the entire learning process continues but uses distance learning or what is called online learning.

Distance learning is a learning process that uses online media or what we often call online learning. Online learning is a medium during this pandemic that is able to bring together educators and students to carry out learning without face to face. According to Moore, Dickson-Deane and
Galen (2011) online learning requires accessibility, connectivity, flexibility and the ability to generate various types of learning interactions. For most educators and students in Indonesia, online learning is still very common, because education in Indonesia, especially at the junior high school level, still uses traditional learning.

So this makes educators and students have to learn more about technology, about using online media for smooth learning processes during this pandemic. And this is not an easy thing, especially in learning a language and especially in learning Mandarin, where learning is Even with traditional learning methods, there are still many difficulties and there are still many educators who are not ready to break away from traditional learning (offline) and many Mandarin language educators in the city of Medan who are over 40 years old and above who do not understand the use of technology, thus causing online learning. more difficult. In addition, online learning requires a higher concentration or focus on student learning. Therefore, the purpose of this research is to find out how effective online learning is in Mandarin lessons at the junior high school level in the city of Medan, especially the Methodist Charles Wesley school during the COVID-19 pandemic.

\section{RESEARCH METHODS}

The type of research used by researchers in this study is a qualitative research type with a data analysis model that is an analytical model of Miles and Huberman (1994). 
The purpose of this study was to describe the situation of online learning of mandarin lessons carried out at the Methodist Charles Wesley school.

The online learning referred to by the researcher is learning that uses learning media that can be accessed via the internet network, namely: WhatsApp, Google Class, Google Meet and Zoom Meeting.

The research subjects were 14 people who were educators and junior high school students from the Methodist Charles Wesley school who used online learning and were grouped based on the responses of the research subjects. Through the responses of the research subjects, it was found that: 1 educator under 30 years old, 1 educator aged 31-45 years, 12 junior high school students, 8 female and 6 male gender, each educator has experience teaching Mandarin above 5 years, while students have studied Mandarin for more than 5 years as well.

The initial research was conducted by providing a survey using a Google form via the WhatsApp application to educators and students. To get accurate research results, the researcher arranged several questions to explore and obtain information from respondents. And the following are the questions that the researcher asked:

1. How are the facilities and infrastructure owned by educators and students in online learning?

2. How effective is online learning in learning Chinese?

The data analysis that the researcher uses is the analysis model of Miles and Huberman (1994) which consists of 3 stages: data reduction (the stage of collecting data from interviews conducted, then the data is grouped), displaying data (the stage of explaining the required data, data that is not needed, discarded), as well as drawing and verifying conclusions (data interpretation stage to draw conclusions according to the phenomena obtained).

\section{RESULT AND DISCUSSION \\ 1. Educators and Students Have Adequate Facilities in the Implementation of Online Learning}

The development of information and communication technology is greatly influenced by the use of the internet, especially during this pandemic (Rahadian, 2017). At the beginning of 2021, it was recorded that $89 \%$ of Indonesia's population had smartphones, $42.57 \%$ of Indonesians owned computers/laptops and around $98.3 \%$ of Indonesians used the internet either through smartphones or computers. This data is relevant to the results of the data obtained through interviews, where this data shows that almost all Indonesians have internet access either via smartphones or laptops and the interview results obtained that all educators and students have smartphones and laptops, as well as adequate internet.

There have been many studies on the importance of using smartphones and laptops in online learning, especially to help students access the internet (Chan, Walker, and Gleaves, 2015). Educators can take advantage of the WhatsApp, Google Class, Google Meet or Zoom Meeting applications in carrying out online learning. The most frequently used learning application is Google Class, where educators can distribute materials, assignments and quizzes in a neat and orderly manner, but it has a weakness, which is that educators cannot interact directly with students, so educators often interact via WhatsApp media for sessions question and answer.

$$
\text { Besides Google Class and }
$$

WhatsApp, the applications that are often used are Zoom Meeting and Google Meet. At the beginning of online learning, educators were a little overwhelmed; where educators were not very familiar with this technology, but schools provided a lot of training for educators, so educators could slowly understand how to use it. The advantages of zoom meetings and Google Meet are that educators can carry out learning directly with students, but the 
disadvantage of zoom meetings is the time limit given for users who do not pay (40 minutes), so often educators have not finished explaining, the meeting has ended and students must re-join, this causes the learning process is not optimal. Zoom meetings and Google Meet both have shortcomings in terms of quota. The quota used is much larger than Google Class or WhatsApp, so if you do online learning from home, educators have to buy more quota and many educators are starting to use wifi to save funds for purchasing quotas. However, after permission from the government for educators to do online learning from schools, this is no longer a problem for educators, because the school provides wifi facilities in schools. However, it remains an obstacle for students because not all parents can provide sufficient quota. Online learning using video conferencing is quite expensive (Naserly, 2020).

In addition, internet services are less stable, where students often complain about no signal or weak signal network, which causes students not to be able to participate in online learning and often get permission, so this is a new challenge for educators when doing online learning. Online learning has a weakness, namely when internet services are weak, the teacher's instructions are less understood by students (Astuti and Febrian 2019).

\section{Effectiveness of Online Learning}

Online learning conducted by Methodist Charles Wesley middle school uses learning applications that can be accessed via the internet. Judging from the answers to the questionnaire, educators and students are happy with the practical and flexible learning process, because it is not constrained by space and time, but educators are a little overwhelmed with material preparation. The way in which the material provided in online learning is delivered will be slightly different from the way in which traditional or conventional learning materials are delivered, in which educators are required to be more creative, more creative in presenting material, and educators are required to use video recording and editing more often, which used to be educators never do so, so educators should devote more time to material preparation. Students are also burdened with more assignments than usual, because in online learning every time after learning there will be an assignment, in contrast to face-to-face learning which sometimes does it in class.

However, educators are still satisfied with online learning, because the material provided by educators is more organized and organized. This makes it easier for students to repeat lessons and students can access the material freely without being limited by time, which if there is a student who is sick, has permission and does not attend class, can get the material easily. The assignments given by educators are also very organized and have clearer collection limits. This can make it easier for educators, students and parents to pay attention to student learning.

Sun et al. (2008) in the study stated that satisfaction with learning is influenced by three things, namely flexibility of time, learning methods and place. In addition to educators, students are also happy with online learning, which is known from student activity, where students actively give opinions because they feel more comfortable and more confident when learning online. Research Sun et al. relevant to the data obtained, where students are more active in expressing their opinions and answering questions.

The results also state that online learning has its own challenges, where educators and students do not meet directly in the learning process. When conducting virtual classes such as using Zoom or Google Meet media, many students do not turn on the video, so when educators explain the material, educators cannot ensure that students really listen to the explanation and really understand the material, so online learning really requires parental cooperation to help supervise students. And in doing 
assignments, many students have difficulty because they do not understand the video material or reading material provided by the educator, and students do not really understand how to collect assignments through Google Classroom media, so that at the beginning of learning, educators must use more time to provide explanations about how to collect assignments and explain in more detail about the assignments given, especially for class VII students, so educators often use WhatsApp chat or WhatsApp Voice Call to repeat explanations so that students can understand them better.

\section{CONCLUSION AND SUGGESTION}

With the COVID-19 pandemic in Indonesia, the government has determined that learning is done online, so that private schools in Indonesia, especially the Methodist Charles Wesley middle school, have started implementing online learning since 2020.

The results show that educators and students have good facilities and infrastructure to carry out online learning and online learning is proven to provide convenience for educators and students where learning can be carried out without being limited by space and time, because all the material provided by educators can be accessed by students at any time. When doing online learning through zoom media or Google meet, students also become more confident in giving opinions.

However, in terms of advantages, there are still disadvantages, namely learning is not properly supervised, so it requires parental cooperation to supervise, as well as the weakness of the internet network and the high cost of the internet being a challenge in online learning.

Acknowledgement: None

Conflict of Interest: None

Source of Funding: None

\section{REFERENCES}

1. Astuti, P. \& Febrian, F. 2019. Blended Learning Syarah: Bagaimana Penerapan dan Persepsi Mahasiswa. Jurnal Gantang, 4(2), 111-119. Accessed on Monday 7 June 2021 at 21.03 WIB. https://doi.org/10.31629/jg.v4i2.1560.

2. Chan, N. N., Walker, C., \& Gleaves, A. 2015. An exploration of students' lived experiences of using smartphones in diverse learning contexts using a hermeneutic phenomenological approach. Computers and Education. Accessed on Tuesday 13 June 2021 at 18.00

WIB. https://doi.org/10.1016Zj.compedu.2014 .11 .001 .

3. Guan. 1986. Jiaoxue Lun Jiaocheng. Shanxi: Shanxi Shifan Daxue.

4. Miles, M. B., \& Huberman, M. 1994. Qualitative Data Analysis Second Edition. SAGE Publications.

5. Moore, J. L., Dickson-Deane, C., \& Galyen, K. 2011. E-Learning, online learning, and distance learning environments: Are they the same? Internet and Higher Education. Accessed on Monday 31 May 2021 at 19.30

WIB. https://doi.org/10.1016/jiheduc.2010.10. 001.

6. Naserly, M. K. (2020). Implementasi Zoom, Google Classroom, dan Whatsapp Group dalam mendukung Pembelajaran Daring (Online) pada Mata Kuliah Bahasa Inggris Lanjut (Studi Kasus Pada 2 Kelas Semester 2, Jurusan Administrasi Bisnis, Fakultas Ekonomi dan Bisnis Universitas Bina Sarana Informatika Jakarta). Bandung: Aksara Public.

7. Nazir, M. 2005. Metode Penelitian. Bogor Selatan: Penerbit Ghalia Indonesia.

8. Rahadian, D. 2017. Teknologi Informasi dan Komunikasi (TIK) dan Kompetensi Teknologi Pembelajaran untuk Pengajaran yang Berkualitas. Garut: Jurnal Teknologi Pendidikan dan Pembelajaran. 
9. Sun, P. C., Tsai, R. J., Finger, G., Chen, Y. Y., \& Yeh, D. 2008. What drives a successful eLearning? An empirical investigation of the critical factors influencing learner satisfaction. Computers and Education. Accessed on Monday, May 31, 2021 at 21.00 WIB. https://doi.org/10.1016Zj.compedu.2006 .11 .007 .
10. Zhu. 2003. Butong Gaoxiao Lanqiu Xuan Xiangke Yunyong Linghui Jiaoxuefa de Shixian Yanjiu. Medan: Shubei Daxue.

How to cite this article: Ivana. The effectiveness of online learning in learning Chinese language. International Journal of Research and Review. 2021; 8(8): 116-120. DOI:https://doi.org/10.52403/ijrr.20210817

$* * * * * *$ 